\title{
Europe's Green Deal offshores environmental damage to other nations
}

Richard Fuchs, Calum Brown \& Mark Rounsevell

Importing millions of tonnes of crops and meat each year undercuts farming standards in the European Union and destroys tropical forests.

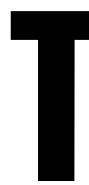
he European Union's Green Deal risks becoming a bad deal for the planet. This ambitious package of policies, announced in December 2019, aims to make Europe the first climate-neutral continent by 2050 (ref. 1). It sets targets to reduce carbon emissions and enhance forests, farming, green transport, recycling and renewable energy. TheEU wants to show "the rest of the world how to be sustainable and competitive", as Ursula von der Leyen, president of the European Commission, said (seego.nature.com/2fnpldz).

Problems lurk behind the rhetoric. First, the EU depends heavily on agricultural imports; only China imports more. Last year, the region bought in one-fifth of the crops and threefifths of meat and dairy products consumed within its borders (118 megatonnes (Mt) and $45 \mathrm{Mt}$, respectively). This enables Europeans to farm less intensively. Yet the imports come from countries with environmental laws that are less strict than those in Europe. And EU trade agreements do not require imports to be produced sustainably.

In the past 18 months, the EU has signed deals (some pending ratification) covering nearly half of its crop imports - with the United States, Indonesia, Malaysia and Mercosur, the South American trade bloc comprising Brazil, Argentina, Paraguay and Uruguay. Pacts with Australia and New Zealand are on the table. Each nation defines and enforces sustainability differently. Many use pesticides, herbicides and genetically modified (GM) organisms that are strictly limited or forbidden in the EU (see Supplementary information, table S2a).

The net result? EU member states are outsourcing environmental damage to other countries, while taking the credit for

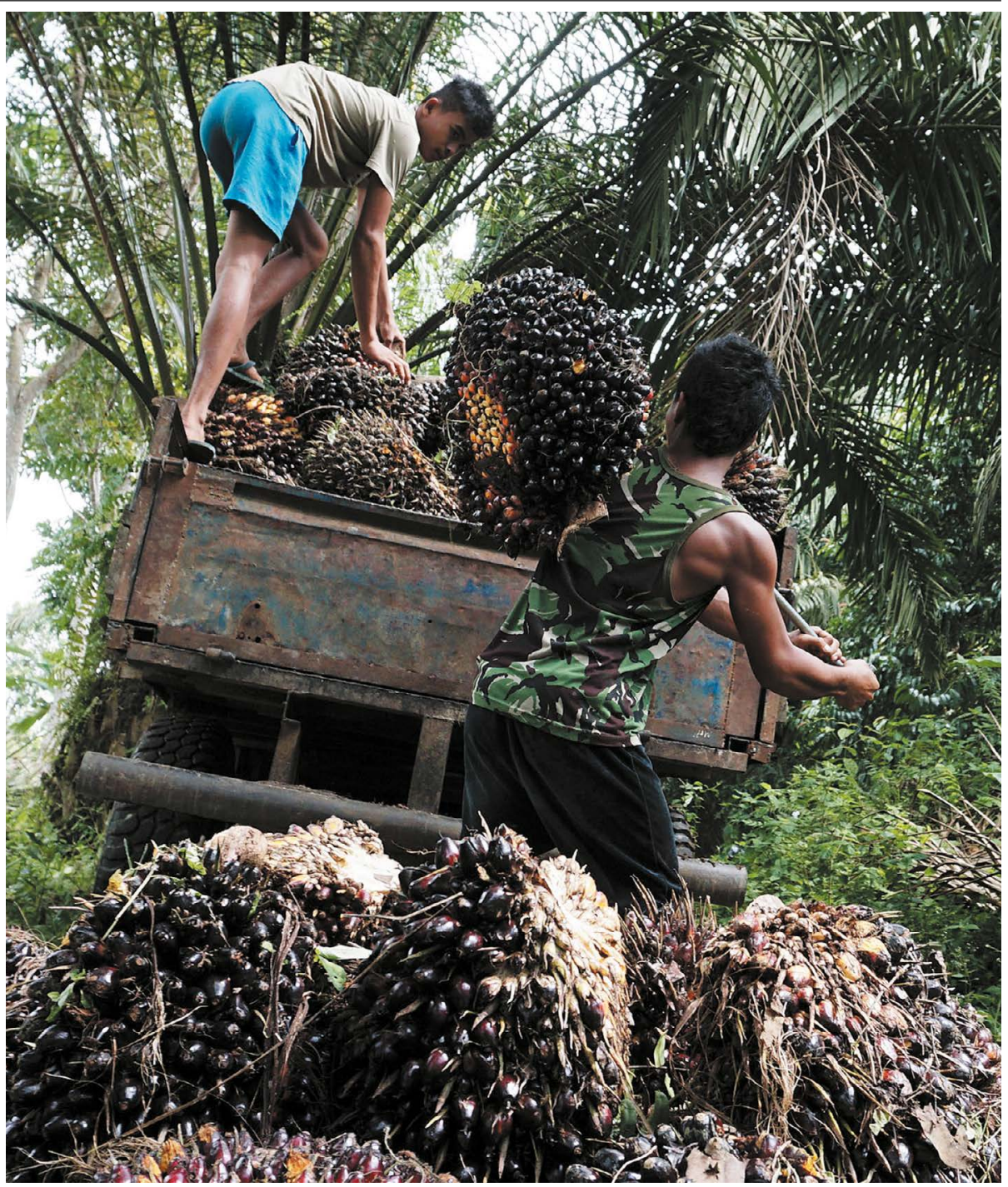

Workers pile palm fruits onto a truck at an Indonesian oil-palm plantation in North Sumatra.

green policies at home. Although the EU acknowledges that some new legislation will be required around trade, in the short term, nothing will change under the Green Deal.

For example, between 1990 and 2014, European forests expanded by $9 \%$, an area roughly equivalent to the size of Greece ( $13 \mathrm{mil}-$ lion hectares; Mha) (see 'Trade-offs'; www.fao. org/faostat/en). Elsewhere, around $11 \mathrm{Mha}$ was deforested to grow crops that were consumed within theEU (seeSupplementary information). Three-quarters of this deforestation was linked to oilseed production in Brazil and Indonesia regions of unparalleled biodiversity and home to some of the world's largest carbon sinks, crucial for mitigating climate change. 


\section{Comment}

Such impacts must be avoided if the Green Deal is to enhance global sustainability. Here, we outline how.

\section{Loose guidance}

The Green Deal will transform European agriculture over the next decade. A farm to fork' initiative aims to reduce fertilizer use in Europe by $20 \%$ and pesticides by $50 \%$, with one-quarter of land to be farmed organically by 2030 . The EU plans to plant 3 billion trees, restore 25,000 kilometres of rivers and reverse the decline of pollinators.

No parallel targets have been set for external trade (see go.nature.com/3703bip). A patchwork of rules, some mandatory and some voluntary, will continue to govern the sustainability of agricultural imports to the EU. All must abide by an overarching policy, the 2018 Revised Renewable Energy Directive. It stipulates, for example, that oilseeds such as soya beans should not be sourced from recently deforested land (see go.nature.com/33vqz86). Such requirements are patchy and poorly enforced.

Customs departments don't have the mechanisms, money or staff to check that goods meet sustainability criteria when they arrive at European ports ${ }^{2}$.EU trade agreements are silent about which specific standards imports must meet, or whether exporting countries should have adequate environmental laws or monitoring. Signatories to the EU-Mercosur pact, for example, agree only to 'strive' to improve their environmental and labour-protection laws.

Voluntary certification schemes fill the gap. These are developed by farming and industry representatives and accredited by the EU. One widely used scheme run by the European Compound Feed Manufacturers' Federation (FEFAC) in Belgium, advises members on which sustainability rules to follow when producing or buying feed. These guidelines cover legal compliance, working conditions, environmental responsibility (avoiding deforestation and protecting nature reserves), agricultural practices and respect for land and community rights.

Some companies define their own benchmarks along similar lines. For example, the US conglomerate Cargill - which trades, purchases and distributes agricultural commodities - promotes its 'Triple S' (sustainably sourced and supplied) standard. Amaggi, the world's largest soya-bean producer, follows sustainability programmes such as ProTerra for its operations in Brazil. Corporate reporting on sustainability remains voluntary, however. Many companies, including Cargill, do not report comprehensively, claiming confidentiality (see go.nature.com/35qmwdd).

Certification rates are therefore low. For example, in 2017,just 22\% of soya used in Europe was compliant with FEFAC's guidelines. Only $13 \%$ was certified as deforestation-free ${ }^{2}$. The EU imports US $\$ 500$ million worth of beef annually from Brazil (see https://trase.earth/explore), most of which is supplied by companies that source meat from newly deforested areas. EU agricultural imports are linked to more than one-third of all deforestation embodied in the global crop trade since 1990 (ref. 3).

This regulatory framework will remain unchanged under the Green Deal, perpetuating its failures. For example, the Renewable Energy Directive ignores past deforestation, specifically land cleared before 2008, the year when the directive was renewed for a second period (see go.nature.com/33vqz86). Farms created on the sites of former forests can thus now be deemed 'sustainable'.

That includes 9 Mha of land, largely in the Brazilian Amazon and Cerrado, that was deforested between 1990 and 2008 (ref. 3). This was done to meet rising EU demand for oilseeds for animal feed and biodiesel - which doubled between 1986 and 2016 (see 'EU import drivers'). The EU grows few oilseeds itself: rape, sunflower and olives comprise just $7 \%$ of all crops on the continent. The bulk of its imports (90\%) come from 8 countries, mainly Brazil. The majority are soya beans and palm oil, which account for half of the EU's crop imports.

Geopolitical tensions are making matters worse. For example, thanks to the current US-China trade war, China is buying more soya beans from Mercosur countries than from the United States ${ }^{4}$. That puts more pressure on land use, and increases the likelihood of deforestation. The EU-Mercosur trade deal (still to be ratified) was agreed in principle in 2019, just as Brazilian President, Jair Bolsonaro, rolled back environmental regulations and Indigenous peoples' land rights. This led to a swathe of deliberate forest fires across the Amazon - more are burning today.

\section{Double standards}

Farming practices that are restricted in Europe are explicitly permitted in imports, not just overlooked. For instance, GM organisms have been severely restricted in EU agriculture since 1999. Yet Europe imports GM soya beans and maize (corn) from Brazil, Argentina, the United States and Canada.

Many GM crops are resistant to herbicides.
For example, $80 \%$ of soya in the United States and Brazil is unaffected by glyphosate, a herbicide that's restricted in the EU. Rates of herbicide application, including glyphosate, have doubled for some crops in the United States in the past 10 years ${ }^{5}$. Europe's trading partners use more than twice as much fertilizer on soya beans on average ( 34 kilograms per tonne of soya bean compared with $13 \mathrm{~kg}$ in the EU). Brazil's use has doubled since 1990, to $60 \mathrm{~kg}$ per tonne in 2014.

Pesticide use has also risen in eight of the EU's top ten trading partners (see 'Tradeoffs'; Supplementary information) ${ }^{6}$ to the detriment of pollinators. Brazil's increasing use of pesticides (with 193 EU-banned pesticides approved since 2016) has been linked to plummeting bee populations. The EU has restricted many of the same pesticides (such as neonicotinoids) for that reason.

\section{From myth to reality}

The EU needs to take the following steps to ensure the Green Deal lives up to its name.

Harmonize sustainability standards. The bloc should streamline and align environmental standards for imports and domestic produce. It should enforce them, with customs checks, and develop and promote a clear certification and labelling scheme. Although the EU cannot enforce standards elsewhere, it can require that goods entering the European market meet its regulations. This can encourage external producers to raise their standards to EU levels; some farmers in Brazil already do so $^{7}$.

Assess global impacts. The EU evaluates some of its agricultural trade impacts on sustainability, including embedded deforestation. But there's no specific benchmark for this trade. The Green Deal should define a standard based on current effects and set targets that go beyond it - assuring big reductions in fertilizer and pesticide use, for instance, and avoiding deforestation and associated emissions.

Roll back bioenergy production. The EU's renewable energy targets, such as the inclusion of $10 \%$ biofuel in diesel by the end of this year (on track to be met), have been the main drivers of an upsurge in soya-bean

\section{EU IMPORT DRIVERS}

Rising demand for biodiesel and animal feed has led the European Union to buy in more oilseeds over the past 30 years.
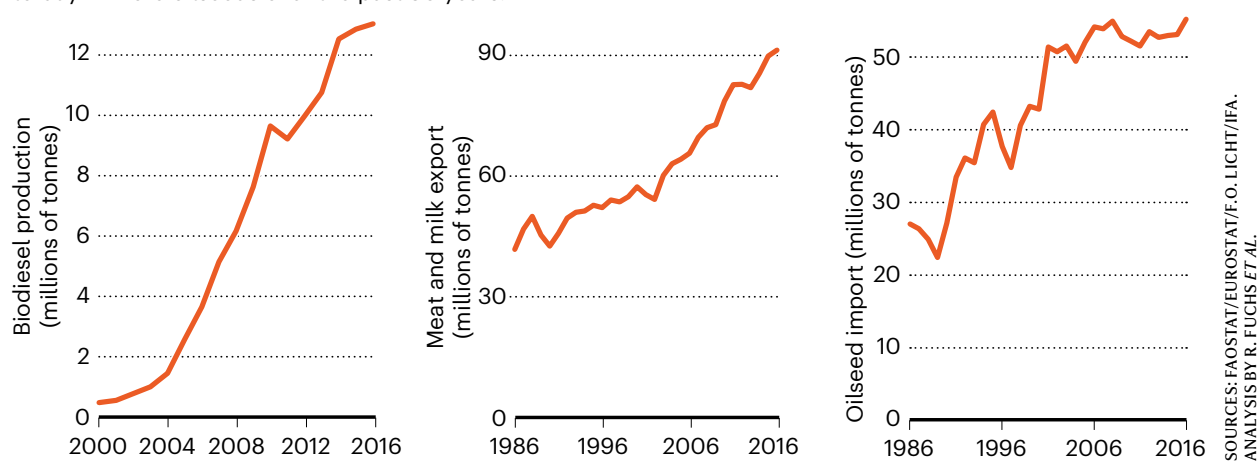
TRADE-OFFS

Compared with the European Union, pesticide and herbicide use and deforestation are higher in several countries supplying oilseeds to the region.

Pesticide use, all crops in 2014

Fertilizer use, soya bean in 2014

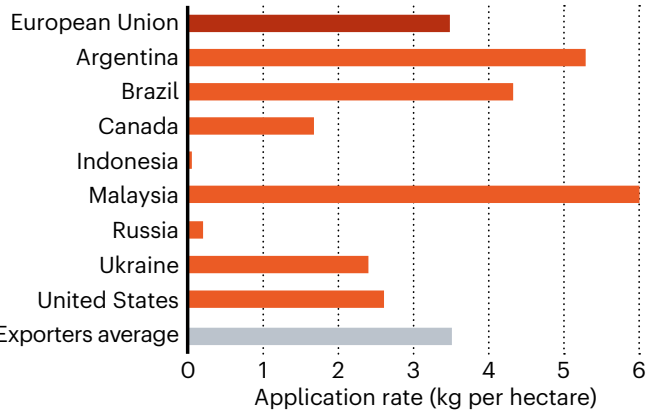

Share of EU oilcrop imports
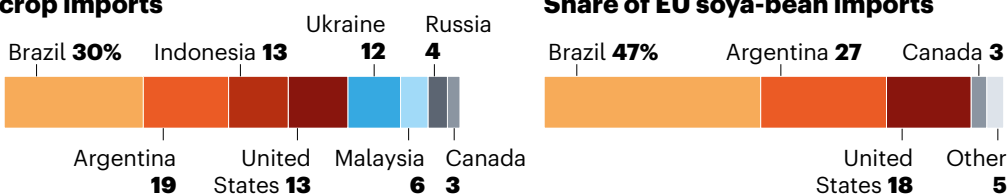

Forestation 1990-2014

Increase in EU

19 States 13

63

States 18

12.6 Mha
Brazil

linked to EU

crop imports

imports from Brazil, by $2 \%$ in 2019 alone (see go.nature.com $/ 34 \mathrm{k} 6 \mathrm{gbt}$ ). A study ${ }^{8}$ highlights the negative impacts of large areas of bioenergy production, including displacing land that could be used for producing food or conserving biodiversity. Reducing or even banning imports of bioenergy feedstocks would support sustainability goals.

Assess Europe's carbon footprint globally. Carbon accounting under the Paris agreement covers only emissions produced within a nation, not those embedded in goods consumed there but produced elsewhere. Each EU citizen currently 'imports' around 1 tonne of carbon dioxide per year in goods entering the EU. The Green Deal risks perpetuating this misstep. Instead, the EU should assess, publish and try to decrease its global carbon footprint.

Decrease consumption. Encouraging Europeans to eat less meat and dairy would reduce the need for agricultural imports. Such reductions are politically difficult, as demonstrated by lobbying for and against 'meat taxes'. They raise moral and ethical questions around international development, food security, access and nutrition. Educational programmes would increase awareness and demonstrate the link between consumption choices and environmental degradation (see www.glopan.org/foresight2). Some costs of environmental damage might be embedded in food prices, provided these do not contribute to food insecurity and inequitable access to nutrition.

Increase domestic production. The EU's reliance on agricultural imports is a result of decades of policies and events that have reduced the area of farmed land. For example, in the 1990s, uncompetitive agro-businesses in Eastern Europe were abandoned following the collapse of the Soviet Union. In the decade that followed, reforms to the EU Common Agricultural Policy (CAP) set subsidies based on area, not production, with the express aim of reducing food production overall. Some of the abandoned land - areas with less biodiversity or non-agricultural uses, for example - should now be returned to farming to reduce pressure in the tropics.

Increasing domestic production will be politically fraught. It might reduce carbon stocks in forests, reduce biodiversity and increase agricultural pollution in Europe. Indeed, updates to the CAP due to come in next year have been criticized for increasing these very impacts and not going far enough in aligning with the Green Deal's environmental objectives. Nonetheless, the EU's food-production systems are high-tech and efficient. We suggest that, even without genetic modification, soya beans could be grown more productively in Europe using less fertilizer and on less land than elsewhere. However, the EU is falling short in explaining the current tradeoffs between imports, domestic production and consumption to its citizens, with no clear strategy to minimize impacts in the future.

In our view, the EU should embrace 'sustainable intensification' practices that use new technologies to boost crop yields. For example, gene-editing techniques (such as CRISPR-Cas) can enhance the edible mass, height and pest resistance of plants without using genes from another species ${ }^{9}$. Unlike the United States and China, the EU is currently treating CRISPR as conventional GM technology and lags behind them in CRISPR patents for agricultural use (18 in Europe, 61 in the United States and 259 in China) as well as in investments in such research ${ }^{10}$.

Indoor farming technologies, such as growing food vertically, are also ripe for development. Although these methods are not yet able to produce staple crops such as soya beans in an energy-efficient way, they are becoming increasingly profitable for vegetables, fruits and tubers, which make up around $18 \%$ of the EU's crop production. Gains in solar energy and lighting would allow more types of crop to be farmed indoors. The EU should pursue research initiatives similar to those under way in the United States, Canada, the United Arab Emirates, Japan, China and Singapore, and consider vertical farming within the CAP.

Reshoring agricultural production will help to insulate Europe's food crops from global market fluctuations, supply-chain disruption and some of the effects of climate change. Because habitat clearance can increase the chance of new infectious diseases jumping from animals to humans, such a policy might also help to avoid future pandemics.

\section{The authors}

Richard Fuchs and Calum Brown are senior research fellows at the Institute of Meteorology and Climate Research, Atmospheric Environmental Research (IMK-IFU), Karlsruhe Institute of Technology, GarmischPartenkirchen, Germany. Mark Rounsevell is a professor of land-use change in the Helmholtz Recruiting Initiative at the IMK-IFU and the Department of Geo-Ecology (IFGG), Karlsruhe Institute of Technology, GarmischPartenkirchen, Germany; and a professor of rural economy and sustainability at the School of Geosciences, University of Edinburgh, UK. e-mail: richard.fuchs@kit.edu

Supplementary information accompanies this Comment: see go.nature.com/3mhkpuq

1. European Commission. A Clean Planet for All (EC, 2018).

2. Kuepper, B. \& Riemersma, M. European Soy Monitor (IDH, IUCN NL \& Profundo, 2019).

3. Cuypers, D. et al. The Impact of EU Consumption on Deforestation (European Union, 2013).

4. Fuchs, R. et al. Nature 567, 451-454 (2019).

5. Hellerstein, D., Vilorio, D. \& Ribaudo, M. (eds) Agricultural Resources and Environmental Indicators, 2019. EIB-208 (USDA, 2019).

6. Dibartolomeis, M., Kegley, S., Mineau, P., Radford, R. \& Klein, K. PLOS ONE 14, eO220029 (2019).

7. Garrett, R. D., Rueda, X. \& Lambin, E. F. Environ. Res. Lett. 8, 044055 (2013)

8. Smith, P. et al. Glob. Chang. Biol. 26, 1532-1575 (2020).

9. Zhang, Y., Pribil, M., Palmgren, M. \& Gao, C. Nature Food 1, 200-205 (2020).

10. Martin-Laffon, J., Kuntz, M. \& Ricroch, A. E. Nature Biotechnol. 37, 613-620 (2019). 